\title{
DIGITAL RESOURCES TO TEACHING AND LEARNING ENGLISH AS A FOREIGN LANGUAGE IN REMOTE CLASSES
}

\author{
Recursos Digitais para Ensino-Aprendizagem de Inglês como Língua \\ Estrangeira em Aulas Remotas
}

Vanessa de Deus ROCHA Programa de Pós-Graduação em Inglês Universidade Federal de Santa Catarina vanessadedeusrocha@hotmail.com https://orcid.org/0000-0002-4093-0822

Luana Garbin BALDISSERA Programa de Pós-Graduação em Inglês Universidade Federal de Santa Catarina luanagbaldissera@gmail.com https://orcid.org/0000-0001-9027-8951

Jeová Araújo ROSA FILHO Universidade Federal Rural do Semi-Árido jeova.araujo@ufersa.edu.br https://orcid.org/0000-0002-9334-4747

\begin{abstract}
Education is one of the areas which has been most impacted by the COVID-19 pandemic, as the social distancing measures adopted by governments affected $90 \%$ of the student population worldwide. The solution found by many educational institutions, including in the Brazilian context, was to adopt Emergency Remote Education (ERE), despite the challenges related to the access to internet and digital technological resources, and the lack of teacher training regarding their use. Having this in mind, this article aims at discussing the concept of ERE, as well as to present and discuss digital technological resources such as platforms and apps which may be used by language teachers to support their pedagogical practice, promoting language development through interaction, increase motivation and learner's autonomy. The article ends presenting the development of a digital story as an activity that may be accomplished through the use of apps. KEY-WORDS: ERE; English as a Foreign Language; Platforms; Apps.
\end{abstract}

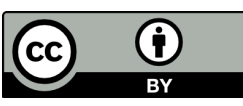


RESUMO: A Educação é uma das áreas que mais tem sido impactada pela pandemia de COVID-19, visto que as medidas de distanciamento social adotadas por governos têm afetado $90 \%$ da população estudantil mundial. A solução encontrada por muitas instituições educacionais, inclusive no contexto brasileiro, foi de adotar a Educação Remota Emergencial (ERE), apesar dos desafios envolvendo a acessibilidade à internet e a recursos tecnológicos digitais, e a falta de treinamento pedagógico em relação a seu uso. Tendo isso em mente, esse artigo busca discutir o conceito de ERE, bem como apresentar e discutir recursos tecnológicos digitais como plataformas e aplicativos que podem ser utilizadas por professores para apoiar suas práticas pedagógicas, promovendo o desenvolvimento da língua estrangeira por meio da interação, e aumento da motivação e autonomia dos alunos. $\mathrm{O}$ artigo se encerra apresentando o desenvolvimento de uma história digital que pode ser realizada por meio do uso de aplicativos. PALAVRAS-CHAVE: ERE; Inglês como Língua Estrangeira; Plataformas; Aplicativos.

\section{INTRODUCTION}

The outbreak of COVID-19 pandemic changed drastically the way people teach and learn around the world. It has been a challenging time for teachers and educators to teach efficiently under social distancing circumstances imposed by governments to prevent the dissemination of the virus. This has been provoking a global and strong impact on education as well as increased gaps in the area (ONEYMA, et al., 2020). The pandemic has affected all aspects of human activities ranging from education, entertainment, social interactions, economy among others, being education one of the areas worst hit by the pandemic (ONEYMA, et al., 2020). According to UNESCO, social distancing measures affected $90 \%$ of the world's student population (HASAN; KHAN, 2020).

With the social distancing measures adopted by governments, students could no longer go to schools and remote classes were abruptly adopted as a way to keep learning happening under these critical circumstances. The challenge now is to make learning accessible and worthy to all students no matter their age or stage (HASAN; KHAN, 2020). To make sure all students and also teachers have access to a good internet connection, appropriate technological devices, and pedagogical instruction to teach remotely seems to be one of the greatest challenges in many countries, especially in a large one with social economic problems as Brazil. 
Aligning technology and pedagogy does not seem to be an easy task, especially considering the pandemic context in which there was no time to prepare and plan how to do it. Technology has already been part of the educational area; however, the pandemic seems to have changed the place it occupies. Now it seems technology has been playing a more central role considering that without it, teaching may not be possible concerning the sanitary measures imposed by governments. Within this context, many digital technological resources have become common to support teachers and also students during classes and also afterwards. This article intends to discuss the concept of Emergency Remote Education and to present and discuss digital technological resources such as platforms and apps that may support teachers during these difficult times from the perspective of a language teacher. The use of apps may provide teachers with endless possibilities of activities that can be developed in remote classes. Thus this article also aims at presenting the development of a digital story as an activity that may be developed through the use of apps.

\section{UNDERSTANDING THE CONCEPT OF EMERGENCY REMOTE EDUCATION}

On the grounds that this article aims at discussing some digital technological resources that might enhance language education in a pandemic world, it is paramount to elaborate on the notion of Emergency Remote Education (ERE), a concept that might be difficult to grasp for two main reasons: firstly, because it has been commonly understood as just another facet of Distance Education; and secondly, because it has been practiced in dramatically different ways from context to context. In order to address such difficulties, this study proposes a critical review of the term, taking into account the particularities of the Brazilian context.

At a first glimpse, the type of remote education practiced in the COVID-19 pandemic might seem similar to Distance Education only with regard to the mediation of digital technologies. However, even this single aspect is debatable when we consider that in Brazil, almost $40 \%$ of public school students do not have a personal computer, and $21 \%$ of them only have cellphones to access the internet (BRASIL, 2020). In face of this context, remote education, for many apprentices, has nothing to do with digital technologies. On the contrary, students are even more excluded from the digital environment, since they no longer have access to school facilities, such as computer labs, and their learning experiences must be restricted to textbooks and printed activities. This 
version of remote teaching or remote class is, in fact, more similar to models of Distance Education of the past century, which was carried out by mail, radio or TV.

Even with these asymmetries regarding accessibility, educational institutions in the whole country have implemented pedagogical practices based on the use of digital platforms, with frequent meetings during the week, following the schedule of face-toface activities carried out before the distance imposed by the pandemic (ALVES, 2020). Such a model of education, although mediated by Information and Communication Technologies (ICTs), cannot be considered as Distance Education. In relation to this, authors such as Hodges, et al. (2020) and Justin, et al. (2020) advocate that the main objective in remote circumstances is not to recreate a new educational model, or a robust online education ecosystem, but to provide temporary access to educational content in a way that it is possible to minimize the effects of social isolation. It is, in this sense, that the term Emergency Remote Education was coined.

In Brazil, legal guidelines regarding the implementation of ERE were firstly elaborated through a document ${ }^{1}$ of the National Education Council (Conselho Nacional de Educação), which states that public and private schools in the country are allowed to offer remote classes while the pandemic lasts. Also, the document highlights that remote pedagogical activities may be implemented exceptionally to meet the regulations set by the Law of Directives and Bases of National Education (Lei de Diretrizes e Bases da Educação Nacional), and it delegates to local education institutions the responsibility to (1) plan learning environments, including technologies to meet the requirements of the curricula; (2) perform synchronous and asynchronous online activities according to learners' accessibility; (3) carry out online or printed evaluative tasks and; (4) use social media (such as Whatsapp, Facebook, Instagram etc.) to stimulate the development of projects that may integrate curricular replanning.

Concerning methodological orientations that might be taken into account on the level of design, the document states that ERE should be implemented (1) by digital means (video classes, content organized on virtual teaching and learning platforms, social networks, e-mail, blogs, among others); (2) through television or radio programs and/or; (4) by the adoption of printed material with pedagogical guidelines.

Although these official guidelines provide a set of orientations which, at a first glance, seem to compose a new educational paradigm, studies in the field of ERE (JOYE, et al. 2020; MOREIRA, SCHLEMMER, 2020) seem to agree on the fact that the principles of this new model of remote teaching follow those of face-to-face education.

${ }^{1}$ CNE / CP Resolution, No. 2, December 10, 2020.

Revista X, v. 16, n. 3, p. 687-702, 2021. 
Here, the dynamics of a physical classroom teaching are transposed to digital media. The process is content-centered and it follows the principles of classroom teaching. Communication is mostly bidirectional, one-to-many, and the physical presence of the teacher and the student are replaced by a digital presence in a digital environment.

Digital technologies, in this scenario, have been commonly approached as a tool for the development of a traditional expository model of education in which students become a mere repository of information, the famous banking education criticized by Freire (2001). The idea of 'remote' therefore, refers only to the change in learning spaces that were once in person, and now are temporarily digital.

In face of this difficult landscape, being a teacher becomes a rather daunting task. Many professionals do not have the expertise to use digital technologies, to create and broadcast online classes, and they end up using remote teaching solutions to perform pedagogical practices that are identical to those of regular physical environments.

Unlike in Distance Education, where teaching practices are shared with a group of specialists who provide the necessary structure, such as educational designers, content teachers, multimedia producers, illustrators and managers of Virtual Learning Environments, in ERE, teachers might become "instructional MacGyvers" (Hodges, et al. 2020) as they feel pressured to present immediate educational solutions without ideal conditions, such as egalitarian access, technological structure and teacher training (JOYE, et al. 2020). That is why the driving force of this article is to discuss technological resources that may offer some support to language teachers, not only approaching an instrumental perspective, but also providing a theoretical debate that might shed light towards a critical evaluation of how technology-mediated teaching practices can be more meaningful in Emergency Remote Education.

\section{DISCUSSION}

As aforementioned, in the context of ERE, the access to digital resources to teachers and learners may be an issue, especially in developing countries such as Brazil. In addition to that, the pedagogical training teachers should undergo in order to implement the use of these resources in Foreign Language classes is, in many times, inexistent. Considering this challenging scenario, this section will present and discuss some digital resources that can be used as a support for teaching and learning English as a Foreign Language during ERE.

As many other digital technological resources that were not developed for pedagogical purposes but were implemented in education (MAYER, 2009), the platforms 
and apps presented in this article had their use widely spread within the field of education since the outbreak of COVID-19 pandemic. When effectively implemented, taking into account learner's needs and following a learner-centered approach, (MAYER, 2009; STANLEY, 2013) such platforms and apps may contribute to the development of a Foreign Language in many aspects, such as by promoting interaction among learners and increasing their motivation and autonomy (STANLEY, 2013). Taken together, the resources presented next allow teachers to hold synchronous and asynchronous meetings, to interact through video, chat, and audio, to split the students into pairs or larger groups, to focus on specific language skills, to deliver and share content, and also to evaluate learners progress.

\section{DIGITAL PLATFORMS TO REMOTE TEACHING: ZOOM AND GOOGLE MEET}

There are many platforms that can be used in ERE, being Zoom and Google Meet two of the most popular among them. Regarding teaching and learning English as a Foreign Language, the free version of both platforms present many features that can be beneficial to meet teachers and learners' needs. Both Zoom and Google Meet can be used to host meetings as synchronous classes with up to one hundred participants for a time limit of 40 minutes (Zoom) or 60 minutes (Google Meet), being any of the attendees allowed to participate either through audio, camera, and chat. As research in the field of Second Language Acquisition has shown, interaction is crucial for Second Language (L2) development to take place (GASS; MACKEY 2015; ORTEGA, 2009). Also, according to Chapelle and Jamieson (2008, p. 203), "it is important to give learners opportunities for interaction in various types of communicative situations". In this sense, teachers may find in Zoom and Google Meet a platform to promote interaction among all participants in a variety of ways, thus, promoting language development.

Zoom also has a feature called Breakout Rooms, through which teachers may split learners in pairs or any group size for a specific period of time to engage in activities, with the possibility of visiting every room as a way to check on the students' performance and to assist them if necessary. By using Breakout Rooms, teachers may encourage not only learners' interaction, but also collaborative work and learners' autonomy. Screen sharing, a feature enabled by both platforms allows participants to share their screen while the others are still able to interact through camera, audio, and chat. However, only Zoom allows the person sharing the screen to look at the other attendee's camera simultaneously, contributing to the sense of social presence for the presenter. Also, according to Vandergrift and Goh (2012), the possibility of watching 
the speaker while listening allows the participants to have access to kinesics cues, such as facial expressions, hand gestures, and other non-verbal clues that can facilitate the interpretation of a message.

Moreover, both Google Meet and Zoom are embedded with the caption option. If the learner desires to use this resource, captions to what is being spoken by the other participants will be shown on the screen simultaneously to their speech, thus aiding participants who may prefer to have access to captions while listening or who may be facing technical problems with their audio in the meantime.

In addition to the free resources aforementioned, both platforms have a premium version that enables to hold longer meetings, with more participants, and that can be broadcast. Also, the meetings in premium versions can be recorded, uploaded, and shared. This allows not only the teacher to hold asynchronous classes, but also learners to go over the class as a way to review the content, or to watch it afterwards, at their own pace, in case any participants were not able to attend in a synchronous class. Finally, besides the possibility of being downloaded on Google Play or App Store to be accessed through their specific apps, Zoom and Google Meet meetings can be accessed by any web browser, thus facilitating the access to a wider range of students, who may not be able to download the platform apps to their device. Table 1 below presents a comparative synthesis between the digital platforms previously mentioned:

Table 1: Comparative synthesis between Google Meet and Zoom.

\begin{tabular}{|c|c|c|c|c|}
\hline $\begin{array}{l}\text { Platform/ } \\
\text { features }\end{array}$ & Accessibility & $\begin{array}{c}\text { Number of } \\
\text { participants } \\
\text { per session }\end{array}$ & Interactional settings & $\begin{array}{l}\text { Time } \\
\text { limit }\end{array}$ \\
\hline $\begin{array}{l}\text { Google } \\
\text { Meet }\end{array}$ & $\begin{array}{l}\text { 1. Free version. } \\
\text { 2. Available on Google } \\
\text { Play and App Store. } \\
\text { 3. Can be accessed by } \\
\text { web browsers. }\end{array}$ & $\begin{array}{l}\text { Up to } 100 \\
\text { participants } \\
\text { in the free } \\
\text { version. }\end{array}$ & $\begin{array}{l}\text { 1. Audio, camera and chat. } \\
\text { 2. Screen sharing. }\end{array}$ & $\begin{array}{c}60 \\
\min \end{array}$ \\
\hline Zoom & $\begin{array}{l}\text { 1. Free version. } \\
\text { 2. Available on Google } \\
\text { Play and App Store. } \\
\text { 3. Can be accessed by } \\
\text { web browsers. }\end{array}$ & $\begin{array}{l}\text { Up to } 100 \\
\text { participants } \\
\text { in the free } \\
\text { version. }\end{array}$ & $\begin{array}{l}\text { 1. Audio Camera and chat. } \\
\text { 2. Screen sharing. } \\
\text { 3. Breakout Rooms. } \\
\text { 4. Screen sharing and } \\
\text { attendees' cameras can be } \\
\text { shown simultaneously. }\end{array}$ & $\begin{array}{c}40 \\
\min \end{array}$ \\
\hline
\end{tabular}

Source: the authors. 


\section{GOOGLE CLASSROOM AND GOOGLE FORMS: PLATFORMS TO SHARE MATERIALS AND EVALUATE STUDENTS}

Google has been offering a range of free online services that have become even more popular nowadays due to COVID-19 pandemic. Besides the e-mail (Gmail), it also provides platforms like Google Docs which allows its users to edit a document online and simultaneously or Google Slides, which allows its users to create presentations online and/ or working collaboratively with other students. Focusing on the educational scenario, Google offers platforms such as Google Classroom and Google Forms which allow teachers to share paperless material and also to evaluate students.

Google Classroom was introduced in Google apps for education in 2014. It can be defined as a free paperless application that may be used by teachers to evaluate students and as share material with them. It is possible to share worksheets, ebooks and also links of videos concerning the topics being studied. Google Forms is one of the programs that can be found within Google classroom. It offers teachers the possibility to provide immediate feedback (DICICCO, 2016), which, according to Brookhart (2008) is quite relevant for feedback to fulfill its purpose of being effective and consequently contribute to learners' knowledge development (DICICCO, 2016). Moreover, teachers and students can use the platform easily from anywhere to complete the assignments, which means that accessibility is one of the advantages of using this application. The only requirement is that teachers and students have a Google account to access the platform.

The platform use is intuitive and it is divided in four sections: mural, activities, people and grades. Mural is for the teacher to leave messages and also to share materials as slides or books with students. It can also work as a reminder of the weekly activities of that group. Activities section is for the teacher to create activities and there are different ways to do that. Teachers can upload a file but they can also create an activity by using Google Forms or even to use an activity that was prepared for another group of students which may be quite useful in case this teacher teaches the same subject in different groups. Each activity can be graded, and teachers and students have access to this in the section grading. The platform does all the calculations necessary to find the final grade.

Providing feedback seems to be crucial in educational contexts considering it is from the feedback that learners may be aware of aspects that still need some improvement and teachers become aware of the aspects that students still have doubts. Feedback may be defined as a teacher's reaction to learners' production with the purpose of correcting, guiding and instructing students (BATTISTELA; LIMA, 2015). Developing activities using Google Classroom may allow the teacher's reaction to be faster than it would be Revista X, v. 16, n. 3, p. 687-702, 2021. 
in case students had to hand in their papers. Students can also have access to teacher's feedback faster, promoting discussion, questioning and consequently solving the doubts.

Developing activities using Google forms offers teachers the possibility to create objective questions that can be automatically corrected. In the case of subjective questions, teachers can also make a comment under each question explaining the mistake and also suggesting any website that could help learners to understand the topic. It is important to limit the number of answers so that students can answer only once, otherwise they will not be able to access the feedback.

Google Classroom may be helping to change the focus of the classrooms from teacher-centered, which tends to be more controlled, to student-centered, being an environment more open do dialogue, development of students' creative thinking and allowing students to become more active participants (SHAHARANEE; JAMIL; RODZI, 2016). The usage of Google classroom may prompt learners to make more observations, to pose more questions, to examine books and other possible sources of information. Learners can also have the opportunity to review what they already know and also make a study plan which probably will allow them to propose answers, explanations and predictions (SHAHARANEE; JAMIL; RODZI, 2016).

Accessibility seems to be one of the major advantages of Google classroom and concerning students' acceptance of this platform, a study conducted at Al Buraimi University College in Oman with 305 students concluded that familiarity in usefulness and ease of use are crucial features of this application. The study also pointed out that students may be able to use Google Classroom to leverage their educational system (MAROOF, et al, 2018). The findings of this study are corroborated by another study which investigated the effectiveness of Google classroom. Results concluded that students are satisfied with the application considering it to be an active learning tool (SHAHARANEE; JAMIL; RODZI, 2016).

Google classroom seems to be an application able to offer advantages to teachers and students. The possibility of providing fast feedback is one of the advantages that may contribute to learners' knowledge development. It also seems to contribute to learners' autonomy development, since they are expected to learn how to use the platform without the teacher's direct assistance, which may lead them to do some research online autonomously or even learn how to do it collaboratively with other colleagues. Sharing paperless material also seems to be another great advantage to the environmental cause. 


\section{THE USE OF MOBILE APPS TO SUPPORT REMOTE TEACHING}

Language teachers may also rely on mobile apps to support their pedagogical practices during ERE. Today, there are a variety of apps which have been developed for language learning and focus on vocabulary development or on the specific skills of writing, reading, speaking, and listening. Apps such as Duolingo, Babbel, Memrize, ABA, Busuu, Elsa, EnglishPronunciation, EnglishPronunciation Tutor, and Elsa are some examples of apps that can be used to develop one or various aspects of English as an L2 and have already been investigated (BALDISSERA, 2020; GONZALEZ, 2012; GUO, 2014; PAIVA, 2017; PAIVA 2018; PIRES; TUMOLO, 2020). There are also apps or mobile embedded features that have not been developed with pedagogical purposes, but have the potential to assist language development, as the example of WhatsApp (SALBEGO, 2019), Intelligent Personal Assistants (MOUSALLI; CARDOSO, 2019), text-to-speech (CARDOSO; SMITH; GARCIA FUENTES, 2015), and social media such as Facebook and Instagram, just to mention a few.

According to Kukulska-Hulme and Shield (2008, p.3) Mobile Learning (ML) refers to "learning mediated via handheld devices and available anytime, anywhere". Such learning may be formal and informal and allows small amounts of time and space for learning (CHINNERY, 2006). In this sense, the use of mobile apps may happen during synchronous classes or in the most suitable time and place for learners, allowing learners to increase the time spent engaged in language learning activities and to practice the language in more naturalistic settings (STOCKWELL, 2013), as when they are not inserted in a class environment. By inserting ML materials in their pedagogical practices, teachers may provide access to a greater variety of input, allow learners to receive immediate feedback, and to increase their motivation and autonomy, either because the apps were properly designed for pedagogical purposes, in the case of language learning apps, or because they are part of learners' personal lives, in the case of social media apps.

However, as these tools proliferate, it becomes difficult to understand how they differ from one another, what their best features are, and what pedagogical benefits may be derived from their use (KUKULSKA-HULME; LEE; NORRIS, 2017). That is why teachers must consider learners' needs and then make a decision on which type of material to use and how. In addition to that, teachers must rely on pedagogical knowledge, and take into consideration principles of Mobile Assisted Language Learning (MALL) materials (STOCKWELL; HUBBARD, 2013) before including them in their practices. The principles include a) the length of the tasks, which must be short and succinct and/ 
or divided into smaller and coherent chunks. This way, the learner is able to engage in language learning activities in small periods of time; b) tasks should be developed to fit that technology and environment and still allow effective learning - one should not expect learners to read long passages in a small screen, or completing listening/speaking tasks in a library; and c) guidance and training for learners are required, regardless if they already use such tools in their personal life.

Taking all this into account, teachers will be able to make informed decisions regarding what are the most relevant mobile apps considering the goals, interests, and difficulties of specific groups of learners, thus not only assisting their Foreign Language development but also increasing their motivation and encouraging learners' autonomy.

\section{DIGITAL STORIES DEVELOPMENT AS AN ACTIVITY PROPOSAL WITH THE USE OF APPS}

Video production may be one of the possibilities that the use of apps during remote classes may offer to teachers and students. The development of digital stories (DS) may be a possibility of video production to be developed in the classroom. According to Tumolo (2015), DS may be defined as a digital resource used by learners to tell stories by selecting digital images, music, text to create a video lasting from two to ten minutes.

The first aspect to be considered when developing a digital story is the topic chosen. The topic needs to be personal, so learners are invited to choose the topic they want to discuss on their stories (JAKE, 2009). Once the topic is chosen, learners move to the next step, script development, when they are expected to write a text to be used in their stories and receive feedback from the teacher to improve their script. The following step involves the development of a storyboard in which learners will match the digital pictures with their text (JAKE, 2009). Lambert (2007) highlights that the pictures need to be chosen with the objective of contributing to the message the story intends to deliver so the author needs to be careful not to overload the audience with unnecessary images.

Once the storyboard is completed, learners are expected to do the audio narration using the pictures they have previously selected and recording their own voices (JAKE, 2009). Considering the personal nature of the digital story, the author is the only one who can do the audio narration. The final step in which learners are expected to create the story by adding pictures and voice can be done using a computer software, but in case this is not available, they can do it using a free app called Speaknphoto. Through this app, learners can take pictures or even select pictures from their galleries. The app also allows them to record their voices to tell their stories. 
Research has shown that the development of digital stories may contribute to learners' language development (ROCHA, 2019; CASTAÑEDA, 2013) but it could also contribute to learners' knowledge development in any area they decide to work on, as long as the story presents their point of view about the topic approached. For example, a student may develop a digital story talking about the Covid-19 pandemic in his community or even discuss the environmental cause or any other subject he has been learning.

Remote classes have been a challenge to teachers and learners. Then, using the tools technology may offer during classes may be a profitable experience which allows learners to even increase their motivation towards learning. Using apps seems to be an alternative with easy access that will allow learners to participate actively by creating their own stories and especially to be heard.

\section{FINAL REMARKS}

As pedagogues, facing the challenges of Emergency Remote Education during the COVID-19 pandemic has been a deep transformational experience. As we converted our homes into classrooms and replaced faces with screens, many of the taken-for-granted aspects of our profession needed to be reconfigured simply because we have never lived something similar before.

It goes without saying that digital technologies would gain deeper proportions in teaching and learning settings over time, but the sudden movement from physical classrooms to completely technology-mediated environments brought to the fore political, social, emotional and methodological issues that we were not prepared to face without enough time for reflection and decision making. That is why the use of digital technologies during ERE has followed a mere instrumental approach and echoed traditional expository teaching practices.

In an attempt to mitigate the difficulties of social isolation in contemporary educational practices and resignify the role of digital technologies in language teaching and learning, this article provided both a theoretical debate on Emergency Remote Education, as well as an illustration of how particular technological resources, such as online platforms and applications, can be used as a way to enhance language development through interaction, to increase learners' motivation, and to foster their autonomy. To conclude, we hope to contribute to the construction of a network of education professionals who, even in the midst of a chaotic context, are able to think critically, to act collaboratively, and ultimately to share possible solutions. 


\section{REFERENCES}

ALVES, Lynn. Educação remota: entre a ilusão e a realidade. Interfaces Científicas, v. 8, n. 3, p. 348-365, 2020.

BALDISSERA, Luana Garbin. App Resources for developing English as an L2: a focus on pronunciation. Master's thesis. Universidade Federal de Santa Catarina, Florianópolis, 2020.

BATTISTELA, Tarsila Rubin; LIMA, Marília dos Santos. A correção em língua estrangeira a partir de uma perspectiva sociocultural e as crenças de professores sobre o assunto. Revista Brasileira de Linguística Aplicada. Belo Horizonte, v. 15, n. 1, p. 281-302, 2015.

BRASIL. Resolução CNE/CP 2/2020 - Institui Diretrizes Nacionais orientadoras para a implementação dos dispositivos da Lei no 14.040. Brasília: MEC, 2020.

BRASIL. TIC educação 2019. Centro Regional de Estudo para o Desenvolvimento da Sociedade da Informação. São Paulo, 2020.

BROOKHART, Susan, M. How to give effective feedback to your students. Association for Supervision and Curriculum development. Alexandria, Virginia USA, 2008.

CARDOSO, Walcir.; SMITH, George.; GARCIA FUENTES, Cesar. Evaluating text-tospeech synthesizers. In F. Helm, L. Bradley, M. Guarda, \& S. Thouësny (Eds.), Critical CALL - Proceedings of the 2015 EUROCALL Conference, Padova, Italy, p. 108-113, 2015. DOI: http://dx.doi.org/10.14705/rpnet.2015.000318.

CASTAÑEDAS, Martha E. I am proud that I did it and it's a piece of me: Digital Storytelling in the foreign language classroom. CALICO, v. 30, n. 1, p. 44-62, jan, 2013

DICICCO, Kathleen, M.; The effects of google classroom on teaching social students for students with learning disabilities, Rowan University, 2016.

FREIRE, Paulo. Pedagogia do Oprimido. São Paulo, Paz e Terra, 2001.

GASS, Susan.; MACKEY, Alison. Theories in Second Language Acquisition. Input, Interaction, and Output in Second Language Acquisition. In: VANPATTEN, Bill; WILLIAMS, Jessica (Eds), Theories of Second Language Acquisition. Routledge, 2015.

GONZALEZ, Jonas Fouz. Can Apple's iPhone Help to Improve English Pronunciation Autonomously? State of the App. Paper presented at the CALL: Using, Learning, Knowing: EUROCALL Conference: Gothenburg, Sweden, p. 22-25, 2012. 
GUO, Hui. Analysing and Evaluating Current Mobile Applications for Learning English Speaking. 2014. Master's thesis. University Of London, Birkbeck, 2014.

HASAN, Naziy; KHAN, Naved Hassan. Online teaching and learning during covid 19 pandemic: student's perspective. The Online Journal of Distance Education and e-Learning, v. 8, n. 4, 2020.

HODGES, Charles et al. The Difference Between Emergency Remote Teaching and Online Learning. Educause Review. Retrieved from: https://er.educause.edu/articles/2020/3/thedifference-between-emergency-remote-teaching-and-online-learning, 2020.

JAKE, D.S. Capturing Stories, Capturing lives: an introduction to Digital Stories. Illinois, 2009.

JOYE, Cassandra Ribeiro; MOREIRA, Marília Maia; ROCHA, Sinara Socorro Duarte. Distance education or emergency remote educational activity: in search of the missing link of school education in times of COVID-19. Research, Society and Development, v. 9. n.7, p. 1-29, 2020.

KUKULSKA-HULME, Agnes; SHIELD, Lesley. An overview of mobile assisted language learning: From content delivery to supported collaboration and interaction. ReCALL, v. 20, n. 3, p. 271-289, 2008.

LAMBERT, Joe. Digital storytelling cookbook. San Francisco: Digital Diner Press, 2007.

MAROOF, Rana; AL-EMRAN, Mostafa. Students acceptance of Google Classroom: An exploratory Study using PLS-SEM approach, 2018.

MAYER, Richard. Multimedia Learning. 2nd Edition. Cambridge University Press, 2009.

MOREIRA, José Antônio; SCHLEMMER, Eliane. For a new concept and paradigm of onlife digital education. Revista UFG, v. 20, 2020.

MOUSSALLI, Souheila; CARDOSO, Walcir. Intelligent personal assistants: can they understand and be understood by accented L2 learners? Computer Assisted Language Learning, 2019. DOI: 10.1080/09588221.2019.1595664

ONEYMA, Edeh Michael et al. Impact of coronavirus on education. Journal of Education and practice, v.11, n.13, 2020.

ORTEGA, Lourdes. Understanding Second Language Acquisition. Hodder Education, 2009. 
PAIVA, Vera Lucia Menezes de Oliveira. Aplicativos móveis para aprendizagem de língua inglesa. Polifonia, Cuiabá, p. 10-31, jan-jun, 2017.

PAIVA, Vera Lucia Menezes de Oliveira. Tecnologias digitais para o desenvolvimento de habilidades orais em inglês. Delta: Documentação de Estudos em Lingüistica Teórica e Aplicada, v. 34, n. 4, p.1319-1351, dez, 2018. DOI: http://dx.doi.org/10.1590/0102445008554706004546.

PIRES, Daniel Reschke; TUMOLO, Celso Henrique Soufen. L2 Vocabulary Instruction: an analysis of smartphone applications for English learning. Revista Diacrítica, v. 34, n. 1, p. 225-247, 2020. DOI: https://doi.org/10.21814/diacritica.303

REICH, Justin; BUTTIMER, Christopher; FANG, Alison; HILLAIRE, Garron; HIRSCH, Kelley; LARKE, Laura; LITTENBERG-TOBIAS, Joshua; MOUSSAPOUR, Roya; NAPIER, Alyssa; THOMPSON, Meredith; SLAMA, Rachel. Remote Learning Guidance From State Education Agencies During the COVID-19 Pandemic: a first look, 2020.

ROCHA, Vanessa de Deus. Digital stories: Students'perception of feedback contribution during script development. Master 's Thesis. Universidade Federal de Santa Catarina, Florianópolis, 2019.

SALBEGO, Nayara Nunes. Online oral negotiated interaction: a study of beginners using WhatsApp. Phd Dissertation. Universidade Federal de Santa Catarina, Florianópolis, 2019.

SHAHARANE, IIzwan; JAMIL, Jastini.; RODZI, Sarah. The application of Google Classroom as a tool for teaching and learning. AIP publishing. University Utara Malaysia, 2016.

STANLEY, Graham. Language learning with technology: Ideas for integrating technology in the classroom. Cambridge University Press. 2013.

STOCKWELL, Glenn. Mobile Assisted Language Learning. In: THOMAS, M.; REINDERS, H.; WARSCHAUER, M. (Eds.), Contemporary Computer Assisted Language Learning. Bloomsbury. p. 201-216, 2013.

STOCKWELL, Glenn; HUBBARD, Phillip. Some emerging principles for mobileassisted language learning. Monterey, CA: The International Research Foundation for English Language Education, 2013.

TUMOLO, Celso Henrique Soufen. Histórias Digitais como recurso para ensino/ aprendizagem de inglês como Língua Estrangeira. Estudos Anglo Americanos, n. 43, p. 101-117, 2015. 
VANDERGRIFT, Larry; GOH, Christine. Teaching and learning second language listening: Metacognition in Action. Routledge, 2012.

Recebido em: 09 mar. 2021.

Aceito em: 03 mai. 2021. 